\title{
Stimulation of Social-Emotional of Children's Digital Natives Through Learning Nawung Sekar Dance
}

\author{
MARIA DENOK BEKTI AGUSTININGRUM \\ Program Studi PendidikanGuru Pendidikan Anak Usia Dini, Universitas IVET, Indonesia. \\ Email: Mdenok14@gmail.com \\ Article Received: 25 October $2019 \quad$ Published Article: 02 May 2020 \\ DOI: https://doi.org/10.29313/ga:jpaud.v3i2.5284
}

\begin{abstract}
Digital Natives is a child born with technological tools in his life. The situation closes the space for real social interaction between humans. The intimate interaction space's impact causes a problem: the development of children's social-emotional abilities. This study aims to provide a useful alternative method to stimulate children's social-emotional abilities properly to improve their quality of life in the future. This study's research method is qualitative research with several multidisciplinary approaches: ethnographic approach, art education approach, and child development psychology approach. The study subjects were digital natives (early childhood children) who studied Nawung Sekar Dance at the Pamulangan Beksa Sasmita Mardawa dance studio in Yogyakarta. This study found stimulation of children's social-emotional abilities in the learning process of Nawung Sekar dance at the Pamulangan Beksa Sasmita Mardawa dance studio Yogyakarta. This was demonstrated through polite manners in Javanese culture through movements implied in the Nawung Sekar Dance.
\end{abstract}

Keywords: Classical Dance Style Yogyakarta; Nawung Sekar; Social Emotion; Digital Natives.

\begin{abstract}
Abstrak
Anak digital natives adalah anak yang terlahir dengan perangkat teknologi dalam kehidupannya, situasi tersebut menutup ruang interaksi sosial antar manusia secara nyata. Dampak dari tertutupnya ruang interaksi secara nyata menyebabkan sebuah permasalahan; yaitu: tidak berkembangnya kemampuan sosial emosi anak dengan baik. Penelitian ini bertujuan memberikan alternative metode yang efektif untuk menstimulasi kemampuan sosial emosi anak dengan benar sehingga mampu meningkatkan kualitas hidupnya di masa depan. Metode penelitian yang dipergunakan dalam penelitian ini adalah penelitian kualitatif dengan beberapa pendekatan multidispliner yaitu: pendekatan etnografi, pendekatan Pendidikan seni dan pendekatan psikologi perkembangan anak. Subyek penelitian adalah anak digital natives (anak yang berusia dini) yang belajar tari Nawung Sekar di sanggar tari Yayasan Pamulangan Beksa Sasmita Mardawa Yogyakarta. Hasil dari penelitian ini ditemukan bahwa terjadi stimulasi kemampuan sosial emosi anak dalam proses belajar tari Nawung Sekar di sanggar tari Yayasan Pamulangan Beksa Sasmita Mardawa Yogyakarta. Hal tersebut ditunjukkan melalui terjadinya pengenalan sikap sopan-santun dalam budaya jawa melalui gerakan-gerakan yang tersirat dalam tari Nawung Sekar.
\end{abstract}

Kata Kunci: Tari Klasik Gaya Yogyakarta; Nawung Sekar; Sosial Emosi; Digital Natives.. 


\section{INTRODUCTION}

The people of Indonesia felt the rapid development of technology as part of the world community. It appears in the use of technology in all lines of community life. The use of technology has a positive impact on people's lives, while the positive impacts are: (1) Facilitating communication between one individual and another individual; (2) Providing convenience to access information; (3) Make it more comfortable to disseminate information; (4) Facilitating the movement of humans to access information and specific needs needed by individual users without being limited by space and time (Forum, Technology, \& Technology, 2018).

The emergence of positive impacts due to the use of technology coupled with the emergence of negative impacts, namely the emergence of new patterns of life for early childhood to adolescents. Even behavioral changes are seen in early childhood to adolescents born in this digital technological situation. Changes in behavior patterns in these children provide stigma or mention in the community, namely digital natives or children born in the digital age, with all the patterns of relationships that accompany it.

Staying connected is a new form of relationship pattern that arises due to technology while staying connected is defined as a form of life that can penetrate space and time by only being in one place but able to connect with several people in the room and different times only through gadgets so that their life needs can be completed quickly and easily.

The staying connected pattern raises different social interactions from the previous era; it means that social interaction carried out by individuals with other individuals does not have to be done face to face or face to face but can be done through a gadget. Ease access to various information and technology, causing adults and children to be lazy to move and move. Most children prefer to sit still to play with gadgets and enjoy the world in the gadget. They assume that the world can be present in their grasp without them having to go out into the world (Vodanovich et al., 2018).

Changes in social interaction due to rapid technological changes directly affect the health and development of early childhood. Adverse effects on children's health are most visible when children spend too much time with gadgets to disrupt children's physical growth (Nadar, 2018). Impact Children are not interested in playing with their peers because they are more interested in playing with digital games, even though playing with peers gives real interaction, and children can experience to socialize.

The impact that arises further children become more difficult to concentrate in the real world, the intention is in the process of interacting with gadgets children are accustomed to do one-way communication so that when in the real world they experience difficulties it is because these children have already accustomed to living in a digital world that only slightly raises errors or distractions (Jin Shin Yee, 2014).

Some of the previous explanations show the other side of technological progress, the side of technology that can provide the potential to establish weak relationships between one child and another child in the real world. The time that is supposed to be spent chatting and interacting directly is reduced because it takes up only to enjoy everything in solitude. The loss of time causes a lack of experience interacting with peers to fail to socialize correctly.

The inability to properly socialize as a child impacts the failure to communicate and socialize when the child is growing up. Because children as individuals who are growing up in society are required to have the ability to socialize correctly and correctly, for their existence in the next life, even children as adults are expected to be able to make a significant contribution to the realization of an established and characterized society (Telkom) \& lis, 2015).

Children's ability to socialize in society is a potential that the child has had since birth as a social-emotional ability. This child's emotional, social ability is mature and useful for the child to survive in society if stimulated correctly. The emotional and social abilities of children are formed through experience with the environment through interaction with other humans around him. It can be understood that children need some appropriate stimulation from parents, families, and communities to complete the task of learning at their developmental age. So 
naturally, if a parent has the task and responsibility to facilitate children's emotional abilities.

Art is an influential medium in stimulating the emotional abilities in humans because art rests on aesthetic taste. Art as a medium has various branches of art, but it is necessary to choose branches of art that can accommodate the child's situation and condition for children's emotional stimulation effectiveness. Dance is a branch of art that uses the body's media as an aesthetic expression; the expression of aesthetic value is contained in the human body's movements.

Children as individuals who like to do mobile activities to express their hearts. This is consistent with the essence of dance itself, interpreted as an expression of humans. Through moving, children also learn something because motion becomes a means for children to learn and gain skill and knowledge (Kusmiyati, 2014).

In Yogyakarta, an interesting phenomenon was found: the increasing number of young children learning classical Yogyakarta style dance in classical dance studios in the Special Region of Yogyakarta from 2014 to 2017. This is called a phenomenon because early childhood existed when This (2015 - 2019) is close to digital technology, so it does not know and like past products (classic). Yogyakarta's classical dance style is a colonial dance product full of cultural meanings and values. Existing values are values that are full of human values.

Human values are values that must be owned by children about living together as a part of society. Society becomes a place where children grow and develop into individuals who are healthy and responsible. Human values have many kinds, which in child development psychology start from the child's emotional abilities.

Emotional, social ability is an essential ability possessed by early childhood and is an ability that develops when getting the correct and maximum stimulation from parents, relatives, and people around them. So the development of children's emotional abilities depends on the stimulation they get from their family and environment.

\section{RESEARCH METHODOLOGY}

This research is a type of qualitative research that aims to describe the Nawung Sekar dance as a method that can be used to stimulate the emotional, social abilities of early childhood. A qualitative approach by looking at the Nawung Sekar dance as a part of art products with scientific truth includes textual and contextual aspects analyzed through a multidisciplinary approach.

This type of social-anthropological research is used to see the Nawung Sekar dance as a local culture product: classical Yogyakarta style. The approach used is a historical approach and functional approach and then determined a social phenomenon's functions. The next approach used is the Art Approach to describe and analyze the structure/form of the Nawung Sekar dance as a dance product with aesthetic value (Hatta; Cecep, 2016).

The field of arts education is used to analyze the Nawung Sekar dance and the accompanying teaching and learning process, while the field of child development psychology is used to analyze the child's emotional abilities. Theories in the science of child development psychology are used to position children appropriately according to their developmental stages.

In this study, the research subjects were children aged 5-8 years who practiced the Nawung Sekar dance in the Pamulang Beksa Sasmita Mardawa Foundation's dance studio in Yogyakarta with a total of 22 girls. The education process can be done at formal and non-formal institutions. The Nawung Sekar dance is also studied in traditional schools as part of the subject matter, but the researchers took the studio as a non-formal institution in this study.

The studio's study location was taken because the studio's intensity and flexibility in conducting observations were higher than that of traditional schools. Then the studio chosen as the location of the study was the Foundation Dance Foundation, Pamasm Beksa, Sasmita Mardawa, with the reason that the Foundation Dance Foundation, Pameks Beksa Sasmita Mardawa, Yogyakarta, was a studio that taught the Nawung Sekar dance as learning material for the first time 
and was proven to create classical dancers of the Yogyakarta style who were qualified and competent.

The methods and instruments used in this study are used to describe the stimulation of the emotional, social abilities of early childhood in the digital age or commonly referred to as digital native children through learning Nawung Sekar dance.

\section{RESULTS AND DISCUSSION}

Culture is shared and shared by the community and then spread outside the community is accepted and even accepted as part of the community. Its existence, which is a part of society, crystallizes into a value that can guide the life together where the culture is created and developed. So that these values manifest in a variety of cultural products, one of them is Nawung Sekar dance.

Nawung Sekar dance is a part of the Yogyakarta style classical dance studied by children, a phenomenon that is manifested as a desire to perpetuate Javanese culture in particular. It is worth mentioning how the Yogyakarta classical dance values manifesting in the Nawung Sekar dance can be learned by children who study at the Pamulang Beksa Sasmita Mardawa Foundation dance in Yogyakarta (Tyas \& Kuswarsantyo, 2018).

Since its inception, the Nawung Sekar dance has been staged several times as a group dance, a mass dance in cultural festivals that are held in several regions, both within the Yogyakarta Special Region province and outside the province as well as outside the country of Indonesia.

The name Nawung Sekar is derived from the Javanese Kawi language, which means "Arranging Flowers" in Indonesian. This name was given by Rama Sasmitadipura for the first time Angela Retno Nooryastuti's mother (48 years old) showed her her dance performance (interview result, Tuesday, June 20, 2017).

The Nawung Sekar dance was explicitly made at the request of Rama Sasmitadipura in 1993, beginning with a form of anxiety he saw children who practice Sari Kusuma dance at the Pujakusuma dance studio not yet having the readiness to dance (joged) so that Rama Sasmitadipura ndawuhi Angela Retno Nooryastuti, S.Sn . and Drs. Sunardi, M.Pd. to make a dance that has a cheerful, light, and fragile nature while still paying attention to all the standard rules (pakem) contained in the Yogyakartastyle women's classical dance.

Gendhing Kenya Menik-Menik becomes the Gendhing accompaniment of Nawung Sekar dance. Gendhing Kenya Menik-Menik is a name given by Mr. Sunardi, who in Indonesian means "Sweet Little Child," while the poetry of the Kenya Menik-Menik is written in Javanese contents tells the joy of a child who is learning to dance.

Nawung Sekar dance is a dance that uses pendapa as a stage, so the dance floor pattern pays attention to the four pillars supporting the pendapa as a titikan.

The Nawung Sekar dance costume is the most straightforward technique of using Yogyakarta-style

classical dance costumes compared to other Yogyakarta-style classical dance costumes, such

as Golek, Srimpi, and Bedhaya. As for the costumes used in Nawung Sekar's dance, Cinde pulls it off by using the belt technique as shown in

figure 1

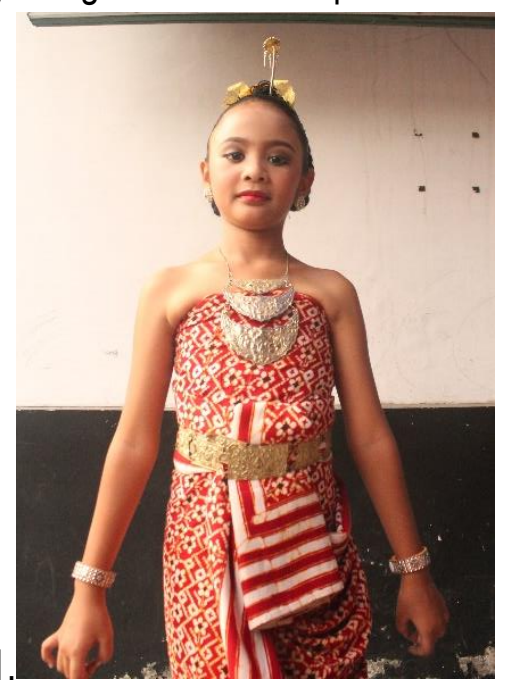

Note: YPBSM students exhibit the Nawung Sekar dance make-up and attire.

The purpose of the Nawung Sekar dance is to introduce or observe the encot or ngurdha movements, which will be used in a variety of standard classical dances for the Yogyakarta style of princesses. The main movements used in the Nawung Sekar dance are (a) Lambeyan, (b) Sembahan, (c) Kicat, (d) Ukel also kiwa-tengen, (e) Going back and forth, (f) ngancap kiwa-tengen, (g) Kengser kiwa-tengen, (h) Encot.

Learning is a process of transferring knowledge from those who know to those who do not know, so the learning practices are carried out 
continuously and occur in educational institutions, both formal and non-formal.

Learning is seen as a constructive process, and the Nawung Sekar dance is a dance that is included in the dance category of girls in the dance curriculum at the Pamulang Beksa Foundation, Sasmita Mardawa, meaning that dance material is given to girls who enroll in a dance course at the Pamulang Foundation dance studio Beksa Sasmita Mardawa.

The routine training process of the Nawung Sekar dance is an activity that is below the command line in the field of education, which will end at the student test stage at the end of each semester. This education sector regulates the course of training activities for one semester in terms of administration and implementation.

Stimulation of the emotional ability appears in the exercise process for \pm six months shown by several achievements to the stimulation of the ability of Social Emotion, namely:

1. It appears in the use of the Q\&A learning method by the teacher, the method done by the teacher at the end of the meeting/learning after giving examples of new movements. This method is in the form of dialectics between teacher and student.

This method can stimulate children's emotional and social abilities because children learn to express their feelings when interesting to the teacher and his friends through questions and statements that are concise and full of family.

As shown in Figure 2.

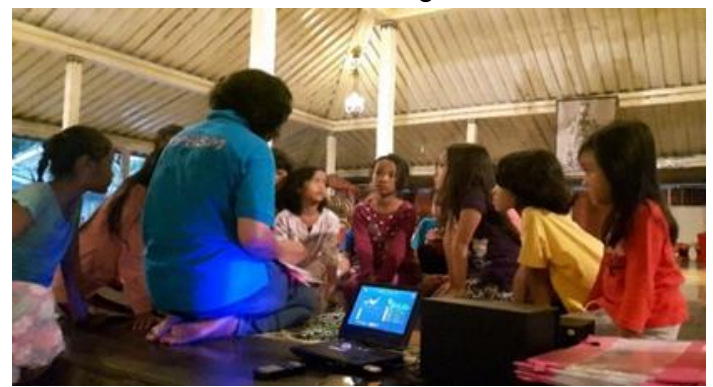

Note: The question and answer process between the teacher and students at the end of the Nawung Sekar dance practice.

2. The use of the Peer Tutor Method in the learning process of Nawung Sekar dance at YPBSM. The Peer Tutor Method is a method in which one of the students is in front dancing and is an example of another friend in the back row.

Through this Peer Tutor method, the facts emerge from the child's social-emotional stimulation, which is that children learn to respect themselves and respect others, as shown in Figure 3.

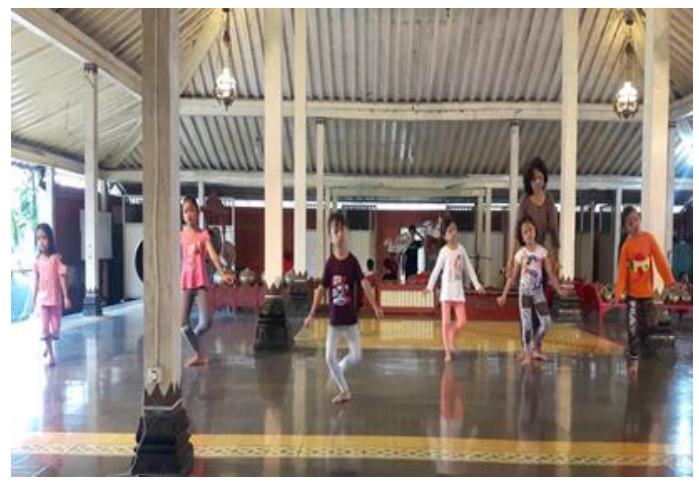

Note: Seen in the picture; a child is in front of other children's lines giving examples of friends who line up behind him.

3. The use of the Rolling method when learning Nawung Sekar dance. The rolling method is the rotation of the line from the first row to the very back row so that the second row becomes the first row.

The application of the Rolling method in the Nawung Sekar dance practice process at YPBSM shows that there is a stimulation of the child's social-emotional ability, namely the child learns to be consistent and queue up for a turn, so the child feels treated fairly.

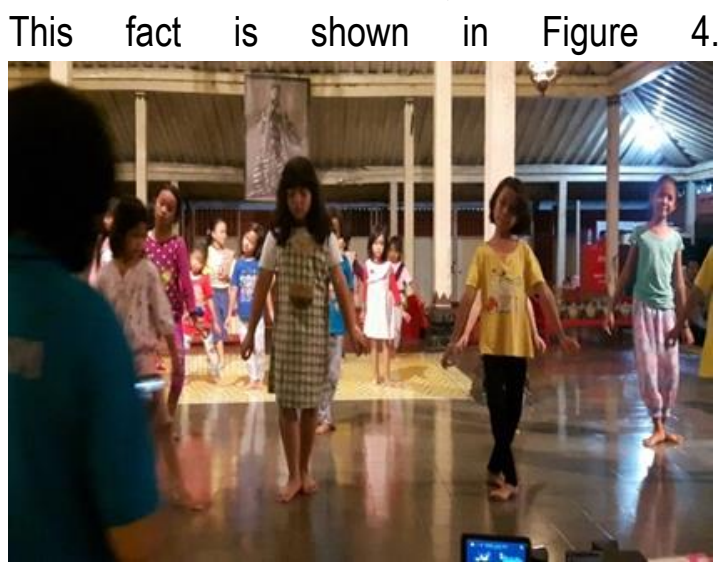

Note: children who line up in the second row during practice get a chance to advance to the first row, so on.

4. The use of worship performed by the children at the beginning of the dance and the end of the dance Nawung Sekar. The worship movement is a mandatory movement that is always performed at the beginning and end of the 
Yogyakarta-style Classic dance. This movement has a philosophy of motion in honor of God and fellow beings the form of a Sembahan pose which is to place both hands in front of the nose, which is considered respectable is a form of appreciation that must be performed by being close to the nose as a member of the body for breathing or the source of life.

The introduction of respect has a meaning or value so that children learn how to behave towards other people or older, especially how children learn to start an activity by respecting other people who are there first (excuse me).

The emergence of the value of respect learned by children in practicing the Nawung Sekar dance appears in learning the Sembahan movement. It respects a form of behavior raised to respect other people, both known and unknown children. Respect is an embodiment of the child's behavior, which can appear as a side effect of the child respecting himself and others.

The process of worship is shown in Figure 4.

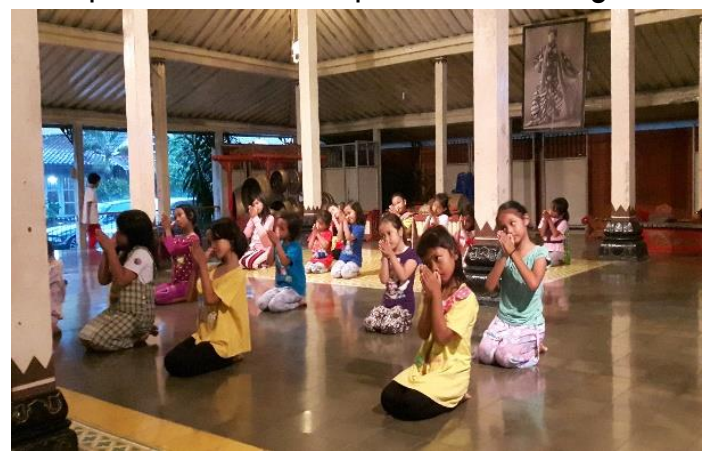

Note: Children do Sembahan movements during the Nauwng Sekar dance practice

Some facts analyzed show that the Nawung Sekar dance can stimulate the abilities of early childhood. Starting from the interest of early childhood, the various effects of learning Nawung Sekar dance can emerge significantly stimulated children's social-emotional abilities so that the effect occurs (Helsper \& Eynon, 2010).

The problems that arise are related to the difficulty of developing emotional, social abilities due to the age and environment situation, which is the impact of rapid technological development for young children born in the digital age or commonly referred to as digital native children able to be answered through learning Nawung Sekar dance.

Nawung Sekar dance, as part of traditional dance, can stimulate the child's emotional abilities to the maximum so that children's learning tasks can be completed entirely. Completing the task of learning the social abilities of early childhood emotion can be interpreted as the mature socialemotional abilities of digital natives.

The mature emotional, social ability becomes the ability to form unique and competitive characters in the current global situation. A global situation that provides a big challenge for children to survive and even become someone who has a strong character that is useful for themselves, and also the nation and country.

\section{CONCLUSION}

Digital children are essentially just early childhood who grow up in the rapid development of technology. So it is appropriate that parents and the environment continue to play an active role in shaping and stimulating children's emotional and social abilities to complete their growth and development tasks well and later become a good human being for their founders, communities, nations, and countries.

As part of the parties who also take part in the education process for digital natives, the government should be able to play an active role by providing space for crocodile-culture in the archipelago that contains the values of local wisdom. Where children grow and develop into mature human beings, considering that Indonesia is a country with cultural diversity, it is only natural for our children to have healthy and cultured character without leaving their national identity.

\section{REFERENCES}

Forum, I., Technology, E., \& Technology, E. (2018). International Forum of Educational Technology \& Society Modelling Digital Natives' International Collaboration : FinnishKorean Experiences of Environmental Education Published by International Forum of Educational Technology \& Society Modelling Digital Natives' International Collaboration : Finnish-Korean, 15(2).

Hatta; Cecep, S. (2016). Upaya pelestarian Adat Semende di Desa Ulu Danau Sumatera Uttara. Journal Of Urban Society's Arts, 3(2), $57-64$. 
Golden Age: Jurnal Pendidikan Anak Usia Dini, Volume 3 Nomor 2 (Desember 2019)

ISSN 2549-8371 | E-ISSN 2580-5843

Maria Agustiningrum/ Stimulation of Social-Emotional of Children's Digital Natives Through Learning Nawung Sekar Dance

Helsper, E. J., \& Eynon, R. (2010). Digital natives: Where is the evidence? British Educational Research Journal, 36(3), 503-520. https://doi.org/10.1080/01411920902989227

Jin Shin Yee. 2014. Mendidik Anak Di Era Digital. Jakarta Selatan: Noura Books.

Kusmiyati, M. F. T. G. L. R. S. A. . H. (2014). NonFormal Education As Culture Transformation Agent Towards The Development Of Clasical Court Dance In Yogyakarta , Indonesia, 2(5), 43-52.

Maria Denok Bekti Agustiningrum. (2014). Penanaman Proses Pendisplinan Diri Anak Berkebutuhan Khusus (Tuna Rungu Wicara) Dalam Pembelajaran Tari Tradisional. Cakrawala Dini, 5(1).

Nadar, S. (2018). A study on impact of electronic gadgts on children's behaviour with refeerence to primary and secondary school children. Concept, 3(3), 209-215. https://doi.org/10.15713/ins.mmj.3

Putraningsih, T. (2007). Perkembangan Tari Klasik Gaya Yogyakarta di Era Global. Tidak Ada Nama, 5(1), 47-59.

Telkom), gitary sharen (Universitas, \& lis, K. (Universitas T. (2015). intensitas penggunaan smartphone terhadap perilaku komunikasi. Jurnal Sosioteknologi, 14(2), 170-178.

Tyas, G. P., \& Kuswarsantyo. (2018). Nilai Pendidikan Karakter Dalam Ragam Gerak Tari Srimpi Pandelori. Mudra, 33(Mei), 182190.

Vodanovich, S., Sundaram, D., Myers, M., Vodanovich, S., Sundaram, D., \& Myers, M. (2018). Linked references are available on JSTOR for this article: Digital Natives and Ubiquitous Information Sy, 21(4), 711-723. https://doi.org/10.1287/isre. 